FOLIA HISTORICA CRACOVIENSIA, 21: 2015, s. 307-310

DOI: http://dx.doi.org/10.15633/fhc.1741

Sławomir Dryja, Maria Działo

Uniwersytet Papieski Jana Pawea il w Krakowie

\title{
Pracownia Dziejów Kultury Materialnej na Uniwersytecie Papieskim Jana Pawła II w Krakowie
}

W październiku 2014 roku podjęto decyzję o utworzeniu Pracowni Dziejów Kultury Materialnej, której kierownikiem został dr Sławomir Dryja. Pracownia, znajdująca się przy ul. Bernardyńskiej 3, zajmuje się dziejami przedmiotów codziennego użytku, technologią ich wytwarzania, kontekstem społecznym, a także ich inwentaryzacją, wstępną konserwacją i dokumentacją. W Pracowni gromadzone są cenne zbiory różnorodnych zabytków archeologicznych: ceramika, ceramika budowlana, kafle, szkło, numizmatyka, wyroby metalowe, kościane, krzemienne, etc.

Podstawową bazę źródłową stanowią zabytki pozyskane podczas badań archeologicznych, zwłaszcza tych, prowadzonych w ramach praktyk dla studentów Instytutu Historii Sztuki i Kultury Uniwersytetu Papieskiego Jana Pawła II w Krakowie. Do tej pory badania archeologiczne z udziałem studentów naszego Instytutu prowadzone były na terenie: dworu renesansowego w Graboszycach w 2011 roku $^{1}$, założenia pałacowego w Setnicy w województwie zachodniopomorskim w 2013 roku oraz kompleksu pałacowo-zamkowego w Mirosławcu, również w województwie zachodniopomorskim². Trzy sezony badań (w latach 2013-2015) doprowadziły do przebadania xviII-wiecznego pałacu należącego do rodziny von Blankenburg. Ustalono również lokalizację xıV-wiecznego zamku, siedziby rodu von Wedel, zniszczonego w wielkim pożarze w roku 1719. Rozpoznano fragmentarycznie narożnik południowo-zachodni, elementy kurtyny zachodniej oraz bramy wjazdowej do zamku.

${ }^{1}$ S. Dryja, Dwór w Graboszycach $k$. Zatora w świetle ostatnich badań - pierwsze fazy budowy (XV-XVII w.), „Wadoviana” 16 (2013), s. 25-48.

${ }^{2}$ S. Dryja, Zamek w Mirosławcu w świetle badań przeprowadzonych w 2013 roku, „Studia i Materiały do Dziejów Ziemi Waleckiej” 5 (2014), s. 52-77. 
Studentom naszego Instytutu prace terenowe dają możliwość zdobycia praktycznej wiedzy na temat badań archeologicznych, podstawowych technik badawczych, sposobów wykonywania dokumentacji archeologicznej i postępowania $\mathrm{z}$ odkrywanymi reliktami dziedzictwa kulturowego. Dzięki współpracy z naukowcami reprezentującymi inne dziedziny nauki (architektami, geodetami, paleozoologami, paleobotanikami, dendrologami, antropologami, etc.) uczą się interdyscyplinarnego podejścia do zagadnień naukowych, pojawiających się $\mathrm{w}$ toku prowadzonych prac.

Po zakończonych badaniach $\mathrm{w}$ terenie studenci uczestniczą $\mathrm{w}$ procesie opracowywania materiału zabytkowego w Pracowni, która jest atrakcyjną alternatywą do prowadzenia zajęć dydaktycznych. Studenci zajmują się inwentaryzacją, wstępną konserwacją, dokumentacją rysunkową i fotograficzną, następnie uczestniczą w naukowym opracowaniu pojedynczych zabytków, jak i całych kolekcji. Ostatecznym celem tych działań jest publikacja naukowa.

W planach Pracowni pozostaje podjęcie działań z zakresu archeologii eksperymentalnej i rekonstrukcji historycznej. Pracownia podejmuje również starania mające na celu pozyskanie środków finansowych w postaci grantów naukowych. 

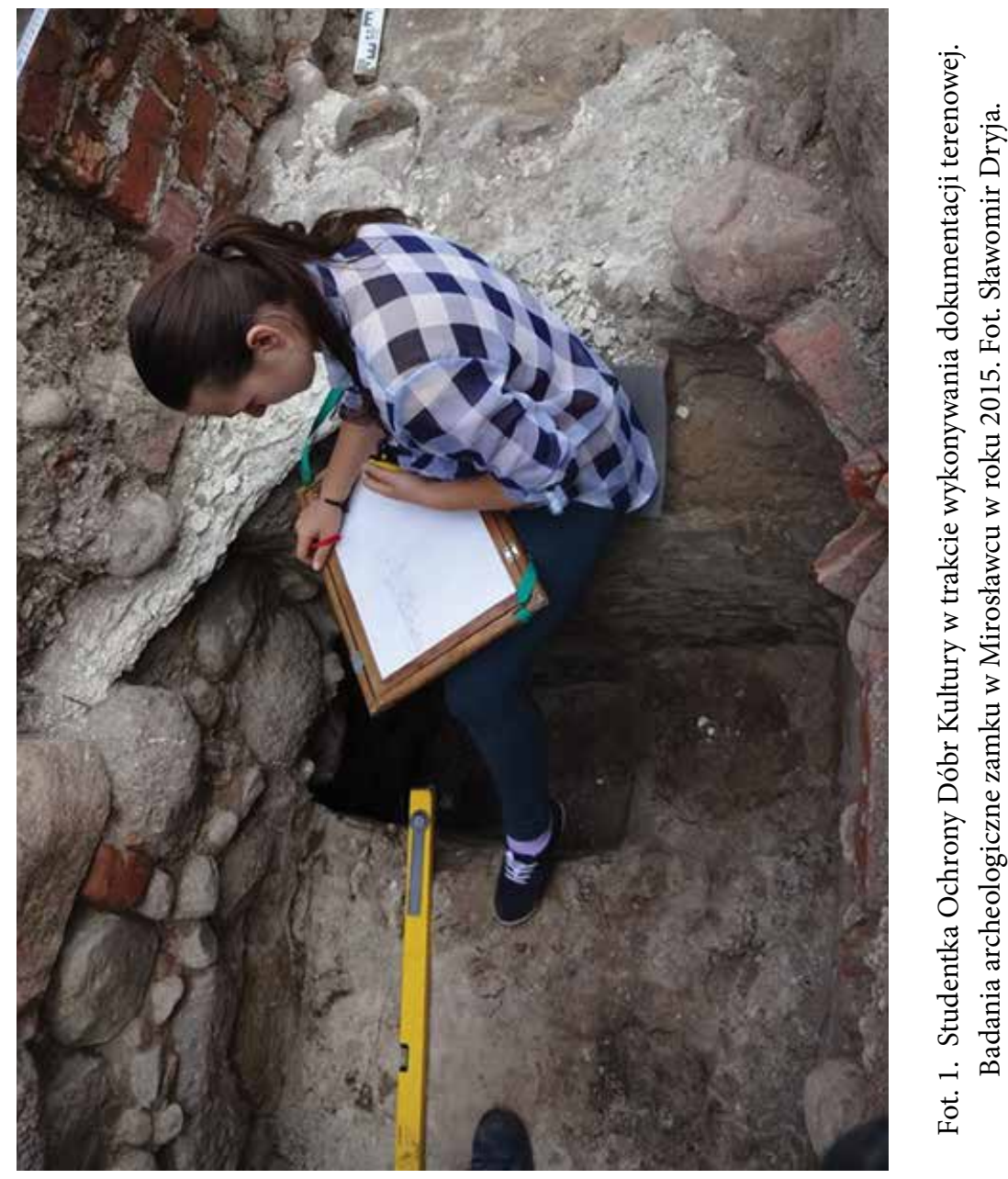

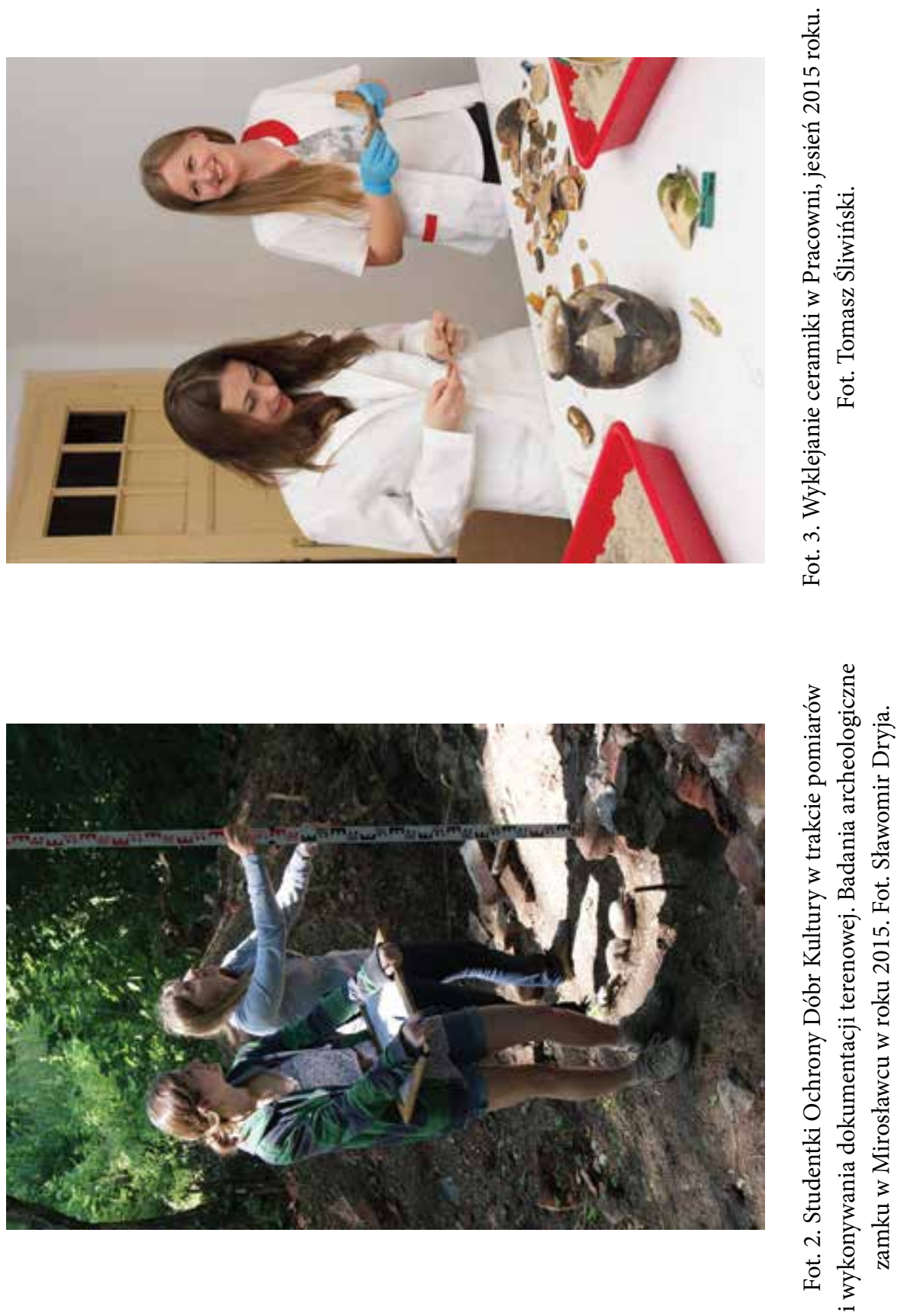